\title{
Yield and Quality of Grafted Watermelon Grown in a Field Naturally Infested with Fusarium Wilt
}

\author{
Benjamín Moreno, Cristián Jacob, Marlene Rosales, \\ Christian Krarup, and Samuel Contreras ${ }^{1}$
}

AdDitional INDEX wORDs. Citrullus lanatus, rootstock, scion, Fusarium oxysporum, Cucurbita maxima, Cucurbita moschata, Lagenaria siceraria

Summary. Grafting of seedlings is a technique used for watermelon (Citrullus lanatus) production in many countries. Because of higher costs involved, the use of grafted seedlings can only be recommended if it provides clear biological and economic benefits. Since rootstock performance is influenced by compatibility with the cultivar, the existing disease pressure, and climatic conditions, it is necessary to evaluate rootstocks with current cultivars to appraise possible benefits in a given area. Two experiments were carried out in two consecutive seasons with the objective of evaluating the benefits of grafting under Chilean conditions. The rootstocks used were 'Marathon' (Cucurbita maxima $\times$ Cucurbita moschata) and 'Macis' (Lagenaria siceraria) with different scions, including some seedless cultivars. In both experiments, grafted plants increased their yield compared with nongrafted plants (136\% and $159 \%$ in Expts. 1 and 2, respectively). This effect was due to an increased number of fruit per plant $(P<0.01)$, and the weight gain of the fruit $(P<0.01)$. Plants presented with fusarium wilt [Fusarium oxysporum $\mathrm{f}$. $\mathrm{sp}$. niveum (FON)] in both experiments, which seemed to be the main limitation for nongrafted plant production. In the evaluation of quality attributes [soluble solid concentration (SCC), firmness, color, polar diameter, equatorial diameter, and rind thickness], positive effects were observed in the fruit of grafted plants. For the conditions of these experiments, the increase in yield of grafted plants would be associated with an economic benefit that exceeds its additional cost.

$\mathrm{T}$ he horticultural production under intensive conditions, with little or no rotation of species, leads to increasing incidence of diseases and yield reduction (Yetisir et al., 2007). Soil infestation by FON and other soilborne fungal pathogens are a major limitation in watermelon production (Miguel et al., 2004). Yield losses of up to $80 \%$ have been reported in watermelon crops affected by this pathogen (Zhang et al., 2012). Fusarium species remain in the soil for years as chlamydospores or as a saprophyte in vegetal residues (Louws et al., 2010). Chemical control of fusarium wilt is limited by the number of chemicals available and their effectiveness (Martyn, 2012), and increasing concern about agriculture sustainability justifies the evaluation and implementation of practices with lower environmental impact (Huh et al., 2012). Grafting watermelon seedlings is a technique that would be effective in reducing damage

Departamento de Ciencias Vegetales, Pontificia Universidad Católica de Chile, Vicuña Mackenna 4860, Santiago, 7820436, Chile

This research was financed by FIA project PYT-20080207

${ }^{1}$ Corresponding author. E-mail: scontree@uc.cl. caused by soilborne diseases (Miguel et al., 2004; Rivero et al., 2003). However, clear biological and economic benefits have to be shown with grafted seedlings to justify the higher cost (Taylor et al., 2008). Since rootstock performance is influenced by compatibility with the scion, existing disease pressure, climatic conditions, and production practices, it is necessary to evaluate rootstocks with current cultivars to appraise possible benefits in a given area.

The use of grafting in watermelon originated in Asia, principally in Korea and Japan, where it has been used since the 1920s (Davis et al., 2008b) and, currently, over $90 \%$ of the production in these countries uses grafted plants (Lee et al., 2010). In Europe and the United States, adoption of this technique is more recent, but it has shown a significant increase during the last two decades (Lee et al., 2010). The main reason justifying the use of grafting watermelon is the yield increase that would be associated with higher plant vigor and resistance to soilborne pathogens (Alan et al., 2007; Miguel et al., 2004; Petropoulos et al., 2012; Yetisir and Sari, 2003). Other reported benefits of this technique in watermelon are fruit quality improvement (Rouphael et al., 2010), resistance to root-knot nematodes [Meloidogyne sp. (Pofu et al., 2012)], more efficient water and nutrients use (Lee, 1994; Pulgar et al., 2000), and higher tolerance to several abiotic stresses, such as salinity (Yetisir and Uygur, 2009), extreme temperatures (Miguel et al., 2004; Rivero et al., 2003), and flooding (Yetisir et al., 2006). However, undesirable effects of grafting have also been reported, which include a reduction in fruit quality (Davis et al., 2008a, 2008b; Rouphael et al., 2010), excessive vegetative growth (Lee, 1994), and losses of plants during fruit development because of incompatibility between scion and rootstock (Hassell and Memmott, 2008). Reported discrepancies in yield and quality effects of grafting may be explained by different production environments and methods, specific rootstock/scion combinations, and difficulties associated with harvesting different cultivars at the same time (Davis et al., 2008a; Rouphael et al., 2010).

Despite advantages described for watermelon grafting, adoption of this technique in many countries is still limited, mainly due to higher costs of grafted seedlings and the uncertainty of its benefits under local conditions (Bruton et al., 2009; Taylor et al., 2008). In Chile, close to 3000 ha of

\begin{tabular}{llll}
\hline $\begin{array}{l}\text { Unit } \\
\begin{array}{l}\text { To convert U.S. to SI, } \\
\text { multiply by }\end{array}\end{array}$ & U.S. unit & SI unit & $\begin{array}{l}\text { To convert SI to U.S., } \\
\text { multiply by }\end{array}$ \\
\hline 0.4047 & $\mathrm{acre}(\mathrm{s})$ & $\mathrm{ha}$ & 2.4711 \\
318.3268 & $\mathrm{fl} \mathrm{oz} / \mathrm{ft}^{2}$ & $\mathrm{~mL} \cdot \mathrm{m}^{-2}$ & 0.0031 \\
0.3048 & $\mathrm{ft}$ & $\mathrm{m}$ & 3.2808 \\
2.54 & inch $(\mathrm{es})$ & $\mathrm{cm}$ & 0.3937 \\
25.4 & inch $(\mathrm{es})$ & $\mathrm{mm}$ & 0.0394 \\
0.4536 & $\mathrm{lb}$ & $\mathrm{kg}$ & 2.2046 \\
1.1209 & $\mathrm{lb} / \mathrm{acre}$ & $\mathrm{kg} \cdot \mathrm{ha}^{-1}$ & 0.8922 \\
4.4482 & $\mathrm{lbf}$ & $\mathrm{N}$ & 0.2248 \\
$\left({ }^{\circ} \mathrm{F}-32\right) \div 1.8$ & ${ }^{\circ} \mathrm{F}$ & ${ }^{\circ} \mathrm{C}$ & $\left({ }^{\circ} \mathrm{C} \times 1.8\right)+32$
\end{tabular}


watermelon are produced per year, and the adoption of grafting has grown significantly during recent years. However, to date, there are no published studies analyzing the benefits of grafting among Chilean watermelon crops. Therefore, the main objective of this study was to evaluate the effects on yield and quality when using grafted watermelon plants under Chilean conditions.

\section{Materials and methods}

The experiments were conducted in Curacaví (lat. $33^{\circ} 26^{\prime} 18^{\prime \prime} \mathrm{S}$, long. $71^{\circ} 01^{\prime} 31^{\prime \prime} \mathrm{W}$; sandy loam soil) over two seasons [Expt. I (2012-13), Expt. 2 (2013-14)]. During the two seasons previous to the experiments, watermelons were produced in the same field, and symptoms of fusarium wilt were observed in the test area.

In Expt. 1, four of the most popular seeded watermelon cultivars grown in Chile were used: Santa Amelia, 1414, Delta (Seminis Vegetable Seeds; Monsanto, St. Louis, MO), and Catira (Nunhems; Bayer CropScience, Leverkusen, Germany). These cultivars were grafted with one of two commercial rootstocks: Marathon (Seminis Vegetable Seeds) and Macis (Nunhems), plus nongrafted plants, resulting in nine treatments (Fig. 1; Table 1). Each experimental unit consisted of a 4-m-long row containing eight plants spaced $0.5 \mathrm{~m}$ from each other, with $2 \mathrm{~m}$ between rows, and five replications arranged in a completely randomized design.

In Expt. 2, four cultivars from Seminis Vegetable Seeds were used: one seeded (Santa Amelia) and three seedless (Kalahari, SV0051WA, and SV7467WD). Each cultivar was grown ungrafted and grafted on Marathon (eight combinations, Table 1). Plants were evaluated in untreated soil and soil treated with metam sodium (Nemasol, Taminco, Ghent, Belgium), applied at a dose of $5 \mathrm{lmL} \cdot \mathrm{m}^{-2}$ through irrigation tapes according to label instructions. Plants were arranged according to a split-plot design (metam sodium application being the main factor), with completely randomized blocks. There were five replications or blocks. Each experimental unit was a 6-m-long row, with seven plants of the given treatment and one plant of a seeded cultivar (Santa Amelia, as the pollen donor). There were $2.8 \mathrm{~m}$ between rows, and within the row distance was $0.75 \mathrm{~m}$.
In both experiments, crop production was carried out according to local cultivation practices, with drip irrigation and black plastic mulch in each row $[0.025 \mathrm{~mm}$ thickness (Acosol Ng; Solplast, Murcia, Spain)]. Grafted plants were obtained by the splice grafting technique. Fertilizer at a rate of 50,25 , and $52 \mathrm{~kg} \cdot \mathrm{ha}^{-1}$ of nitrogen $(\mathrm{N})$, phosphorus $(\mathrm{P})$, and potassium $(\mathrm{K})$, respectively, was incorporated into the soil during bed preparation. Additionally, fertilization with $\mathrm{N}, \mathrm{P}, \mathrm{K}$ at rates of $16,4.6$, and $14 \mathrm{~kg} \cdot \mathrm{ha}^{-1}$, respectively, was applied through irrigation 4,5 , and 6 weeks after transplanting. During Expt. 1 , insects were controlled with a standard foliar spray of thiamethoxam + lambda cyhalothrin (Engeo 247 ZC; Syngenta Protecao de Cultivos, Paulinia, Brazil) 3 weeks after transplant. No fungicides were applied during plant cultivation.

Yield eVAluation. The fruit were harvested three times per week using visual maturity indices specific for each cultivar, such as size, desiccation level of vine tendril proximal to fruit, and epidermal color and brightness. For yield assessment, all harvested fruit were individually weighed in the field.

Quality eValuation. In each experiment, five representative fruit from each treatment were chosen for quality assessment in the laboratory. Each fruit was cut along the equatorial plane and one half was randomly designated to quantify pulp color and SSC, and the other half to measure pulp firmness. Each of these parameters was measured in three equidistant areas from the middle of the pulp (between the center and the epidermis). The SSC percentage was determined by the extraction of $40-\mathrm{mm}^{3}$ pulp cylinders that were squeezed and measured with a digital refractometer (Master T; Atago, Tokyo, Japan). Pulp color was measured with a handheld chroma meter (CR-400; Konica Minolta Sensing, Osaka, Japan), provided with a glass light projection tube, which allowed measuring wet surfaces. Only the $\mathrm{a}^{*}$ dimension of the CIELAB color space, which runs from green $(-60)$ to red $(+60)$, was used for quantification since its values best indicate the variation in perceived red color (Konica Minolta Sensing, 2007). Pulp firmness in Newtons was measured with an automatic fruit pressure tester (Fruit Texture Analyser; Güss Manufacturing,
Strand, South Africa), equipped with an 8 - $\mathrm{mm}$ tip at a speed of $10 \mathrm{~mm} \cdot \mathrm{s}^{-1}$. When necessary, watermelon halves were cut to get slices that fit in the pressure tester equipment. Rind thickness, or distance from the outer edge of the fruit to the boundary between white mesocarp and colored endocarp (Gusmini et al., 2004), was measured at two points of each half with a digital caliper.

Pathogen isolation AND IDENTIFICATION. During both seasons, tissue samples were collected from watermelon plants showing symptoms of wilting, gumming and cracking in the stems, and lower stem and crown browning. In Expt. 1, one symptomatic plant per replication $(n=5)$ was selected, and tissue was sampled from the crown for nongrafted plants and from the rootstock and the scion for grafted plants. In Expt. 2, tissue was sampled from symptomatic stems. In the laboratory, stems and crowns of diseased samples were washed in running tap water and cut into small blocks $(1.5 \mathrm{~cm})$ for isolation. For isolation of Fusarium species, the blocks were surface-sterilized with $1 \%$ sodium hypochlorite for $3 \mathrm{~min}$. The pieces were washed three times in sterile distilled water and then dried on sterile paper towels for $10 \mathrm{~min}$. Once dried, the samples were placed in petri dishes containing potato dextrose agar (PDA) and incubated for $15 \mathrm{~d}$ at $25{ }^{\circ} \mathrm{C}$ in darkness.

In Expt. 2, two colonies were isolated in petri dishes with PDA medium; one from a grafted plant (sample 2G) and one from a nongrafted plant (sample 6NG). After $15 \mathrm{~d}$, the mycelium was extracted from each sample using a scalpel, and DNA extraction was carried out using an adapted protocol described by Lodhi et al. (1994).

Two internal transcribed spacers (ITS1 and ITS2) and the inverting $5.8 \mathrm{~S}$ coding rDNA were amplified by polymerase chain reaction (PCR) using the universal primers ITSI and ITS4 as described by White et al. (1990). The amplified product was directly sequenced (Macrogen, Seoul, Korea), edited using the software Geneious 4.8.3 (Biomatters, Auckland, New Zealand), and finally compared and identified through BLAST-n tool of the National Center for Biotechnology Information database. Also, the isolated colonies were morphologically identified using a microscope 

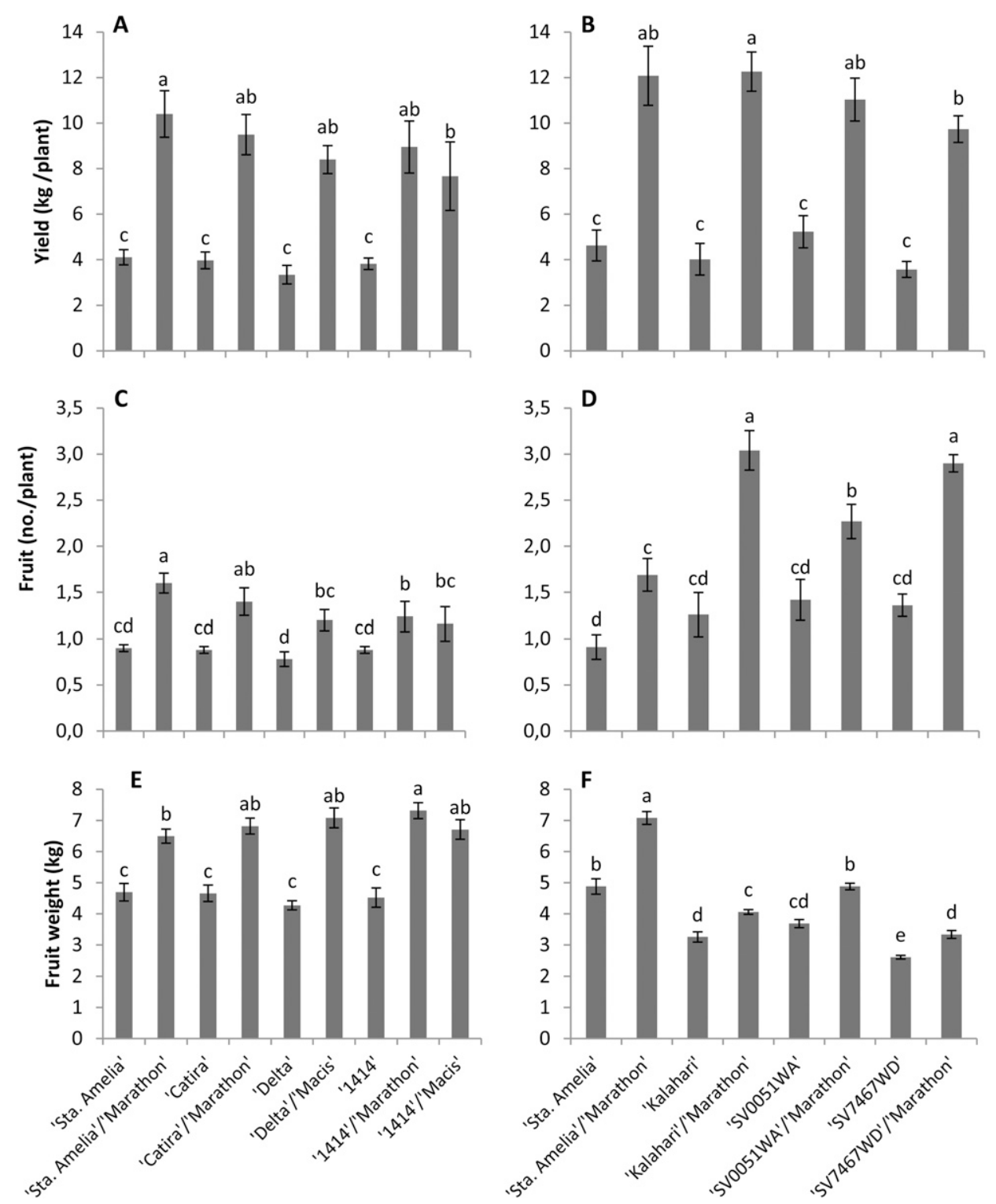

Fig. 1. Watermelon yield components for treatments consisting in different nongrafted and grafted (scion/rootstock) combinations in Expts. $1(\mathrm{~A}, \mathrm{C}, \mathrm{E})$ and $2(\mathrm{~B}, \mathrm{D}, \mathrm{F})$. Data represent the average of five (Expt. 1) or ten (Expt. 2) replications and its sE. In each graph, data with the same letter are not statistically different via least significant difference test at $\alpha=0.05 ; 1 \mathrm{~kg}=2.2046 \mathrm{lb}$.

(BA410 Trinocular; Motic Asia, Causeway Bay, Hong Kong).

Pathogenicity test. The isolate $2 \mathrm{G}$ was tested for their pathogenicity on apparently healthy and uniform 'Sugar Baby' watermelon plants, described as a cultivar susceptible to fusarium wilt (Kleczewski and Egel, 2011). Two plants were inoculated at the first flower stage: one was artificially injured in the roots using a scalpel to promote the infection and was inoculated with distilled water containing Fusarium species conidia and mycelium; the other plant was artificially injured in the stem $(3-\mathrm{cm}$-long cuts made with scalpel), then fungal conidia and mycelium were directly added to the wounds and covered with laboratory film (parafilm M; Bemis Flexible Packaging, Neenah, WI). Inoculated and healthy controls plants were placed in a greenhouse. Fusarium symptoms in inoculated plants became evident after $18 \mathrm{~d}$. Samples of the affected tissue were taken, and the fungus was reisolated to prove Koch's postulates.

Data Analysis. Data of the experiments were analyzed with an analysis of variance. Significant differences among treatments $(P<0.05)$ were determined using the least significant difference test at $\alpha=0.05$. Contrasts were used to compare the average values of grafted and nongrafted treatments.

\section{Results and discussion}

YIELD. Results of fruit productivity for different treatments in Expts. 1 and 2 are presented in Fig. 1. In Expt. 2 , grafted and nongrafted plants were grown in both, soil treated with metamsodium and untreated soil. Cultivation of treatments in fumigated soil was included to evaluate grafting benefits in a soil with lower disease pressure. However, soil fumigation with metam sodium did not have an effect on number of fruit per plant $(P=0.81)$, fruit weight $(P=0.68)$, or fruit yield $(P=0.85)$. 
Table 1. Quality characteristics of watermelon fruit harvested from different rootstock/scion combinations in two experiments.

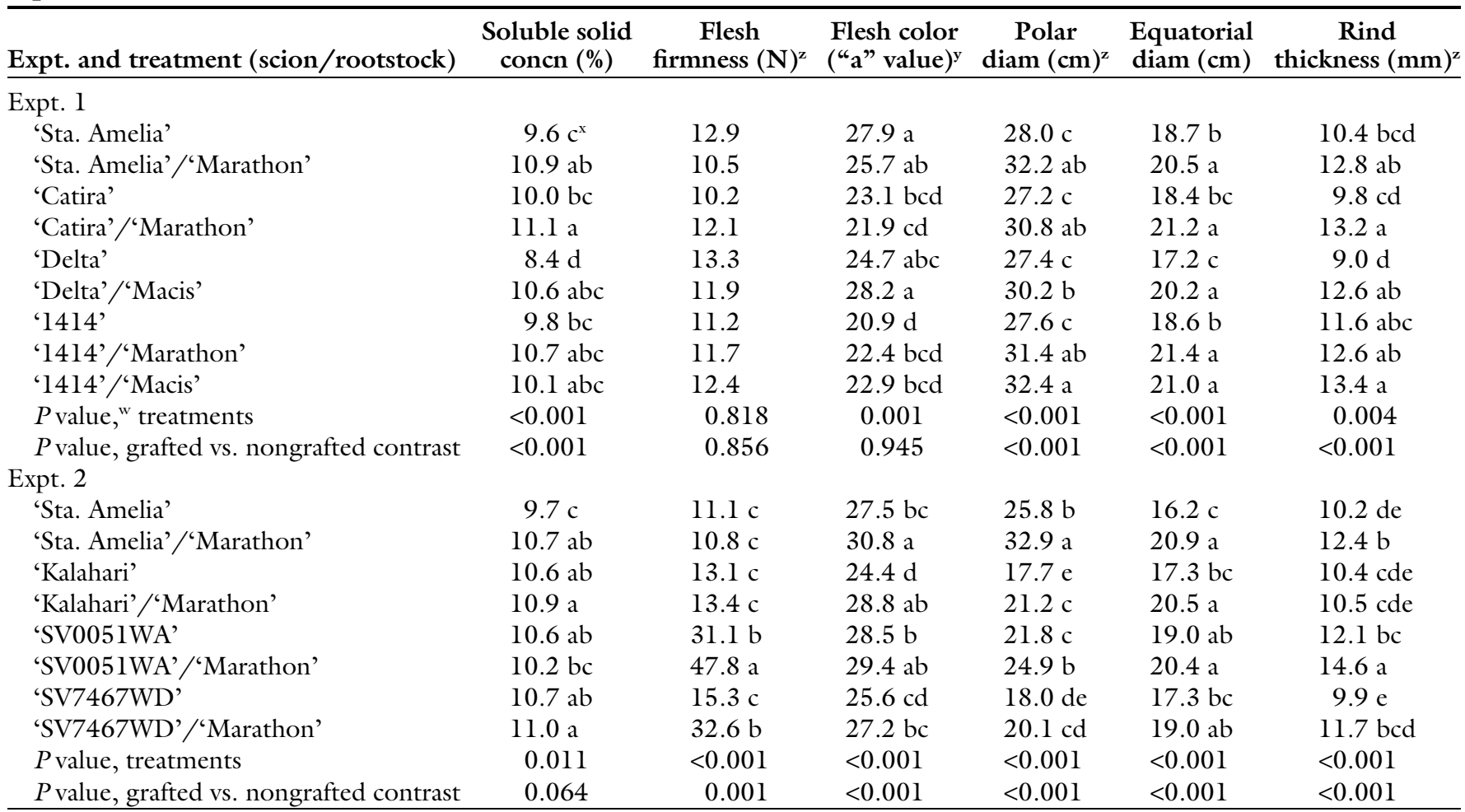

${ }^{\mathrm{z}} 1 \mathrm{~N}=0.2248 \mathrm{lbf} ; 1 \mathrm{~cm}=0.3937 \mathrm{inch} ; 1 \mathrm{~mm}=0.0394$ inch

yColor values "a" measured with colorimeter (CR-400; Konica Minolta Sensing, Osaka, Japan) indicates intensity of red color.

${ }^{x}$ For each experiment, means in the same column with different letter(s) are significantly different according to least significant difference test at $\alpha=0.05$

"Probability value from analysis of variance.

Therefore, subsequent analysis to compare the eight treatments of grafted and nongrafted plants was performed combining data from treated and untreated soil (Fig. 1B, D, and F).

In both experiments, significant differences $(P<0.001)$ among treatments were observed for fruit yield per plant (Fig. IA and B). Independently of the rootstock/scion combination, productivity of grafted plants was always higher than nongrafted plants; average marketable yield of grafted treatments was 2.4 and 2.6 times the average of nongrafted treatments in Expts. 1 and 2, respectively. These differences in productivity were explained because plants of a same cultivar produced more (Fig. IC and D) and heavier (Fig. IE and F) fruit when grafted.

In general, when grafted, seeded cultivars presented a relatively higher effect in fruit weight than in fruit number (Fig. IC and E), while seedless cultivars had greater increase in fruit number than in fruit weight (Fig. ID and F). Seeded cultivars are predominant in Chile, and fruit size is an important quality attribute determining market value. Therefore, a larger fruit size is an important benefit for growers oriented to local markets. Seedless cultivars are still a novelty in Chile and are produced basically for niche markets, where a moderate fruit size is preferred.

Grafting effects on watermelon productivity observed in our experiments are in agreement with results from other studies. Significant increases of watermelon yield because of grafting has been reported by several authors (Davis et al., 2008a), and this positive effect has been mainly attributed to soilborne disease resistance (Miguel et al., 2004; Mohamed et al., 2012; Salam et al., 2002) and more vigorous growth of grafted plants (Yetisir and Sari, 2003). Studies that have compared watermelon yield of grafted and nongrafted plants in soils infested with $F$. oxysporum have shown increases of $125 \%$ (Miguel et al., 2004; Mohamed et al., 2012) and 250\% (Salam et al., 2002 ) when grafted. Yetisir et al. (2003) reported that grafted watermelon plants increased in dry weight by up to $180 \%$ and fruit number by up to $100 \%$ compared with nongrafted plants.
In Expt. 2, fumigation with metam sodium had no significant effect on fruit production. A similar result was observed in an experiment by GonzálezTorres et al. (1993), where no significant differences in yield were reported in watermelon grown in soil with the application of metam sodium, but a delay in the development of the disease was observed. In the same study, the effect of fumigation with metam sodium in a soil artificially infested with $F$. oxysporum tripled plants yield. Martyn (2012) indicates that for both susceptible and resistant plants, the soil inoculum level of this pathogen influences the damage. Soils with high concentrations of inoculums, or where the application of chemicals was not conducted properly, would be unable to achieve a significant decrease in the amount of inoculums, so that applications might not positively impact plant performance.

FruIT QUALITY. Results of fruit quality attributes for different treatments in Expts. 1 and 2 are presented in Table 1. No significant differences were found in color and firmness between fruit of grafted and nongrafted 
plants in Expt. 1, but grafted plants produced fruit with higher SSC, rind thickness, and diameter than nongrafted plants. In Expt. 2, fruit from 'Sta. Amelia' had SSC values consistent with those observed during Expt. 1, i.e., grafted plants produced fruit with higher SSC than fruit from nongrafted plants. Fruit from seedless cultivars did not have significant differences in SSC. Contrary with results from Expt. 1, fruit from grafted plants had higher values of flesh firmness and red color ("a" value) than fruit from nongrafted plants. Similarly, in Expt. 1, diameter and rind thickness increased in fruit from grafted plants.

A decline in SSC is one of the most cited effects of grafting on quality of vegetable fruit, and reductions of $0.5 \%$ to $1.0 \%$ are commonly reported in grafted watermelons (Alexopoulos et al., 2007; Davis et al., 2008a, 2008b; Kyriacou and Soteriou, 2015; Rouphael et al., 2010). However, nonsignificant (Bekhradi et al., 2011; Bruton et al., 2009; Miguel et al., 2004; Mohamed et al., 2012) and positive effects of grafting on SSC (Oluk et al., 2012; Salam et al., 2002) have also been reported. Davis and Perkins-Veazie (2005) studied the effects of grafting a seeded and a seedless cultivar on different rootstocks, observing that only the seeded cultivar had a reduction of SSC as a consequence of grafting. In our study, no difference of SSC was observed in seedless cultivars, but an increase was observed in seeded cultivars when grafted (Table 1). This result may be partially explained because good rootstock/scion compatibility and FON negative effects on sugar accumulation of fruit from nongrafted plants. Salam et al. (2002) studied the effects of using grafted watermelon plants in an FON-infested soil and observed that fruit from grafted plants had higher SSC than fruit from nongrafted plants $(12.5 \%$ vs. $10.2 \%)$.

In both experiments, the values of rind thickness and fruit size obtained from grafted plants were significantly higher than the fruit of nongrafted plants, which is consistent with reports from other authors (Salam et al., 2002; Yetisir and Sari, 2003; Yetisir et al., 2003). Increased rind thickness improves the postharvest integrity of the fruit by reducing damage during transport (Rouphael et al., 2010). The ratio between polar and equatorial diameter may be used to characterize and compare fruit shape. Despite the size increase observed in fruit from grafted plants, no significant difference in fruit shape was observed between grafted and nongrafted plants of a same cultivar $[P>0.15$ (data not shown)].

No significant difference among treatments was seen in Expt. 1 for flesh color or firmness, but in Expt. 2, grafting significantly increased the color and firmness of the fruit. The variation of these attributes, depending on the graft combination, has also been observed by Davis and PerkinsVeazie (2005) and Oluk et al. (2012). Kyriacou and Soteriou (2015) reported that grafting increased flesh firmness and intensity of red color in diploid watermelons.

Along with higher establishment costs, a negative effect in fruit quality is one of the main concerns of watermelon producers in relation to the use of grafted plants. Common quality problems reported for watermelon include reduced SSC, insipid taste, presence of yellowish bands in the flesh, low flesh firmness, internal flesh breakdown, and a fibrous texture (Davis et al., 2008a, 2008b; Kyriacou and Soteriou, 2015; Rouphael et al., 2010). However, none of these problems were observed in our study and, when significant differences existed, fruit from grafted plants presented higher quality (Table 1). There are several conflicting reports regarding effects of grafting on watermelon fruit quality, which would be explained mainly by specific rootstock/scion combinations, environment, and production practices (Davis et al., 2008b; Rouphael et al., 2010). According to Davis et al. (2008a, 2008b), frequency of negative quality issues in grafted cucurbits would decrease as a consequence of rootstock breeding and screening for best rootstock/scion combinations.

Pathogen isolation and IDENTIFICATION. Isolates from both experiments were first tentatively identified as Fusarium species based on morphological characteristics. Tissue samples isolated from diseased plants resulted in creamy orange colonies on PDA, and microscopic observation revealed the presence of fusiform macroconidia, typically having three to five cells (not shown). In Expt. 1, the four nongrafted cultivars presented
Fusarium species based on morphological identification: 1414 (four of five plants), Catira (three of five), Delta (four of five), and Sta. Amelia (five of five). Otherwise, grafted plants did not present Fusarium species in scion tissues, and the fungus was scarcely isolated from rootstock tissues (data not shown).

In Expt. 2, the sequences of the ITS region of isolates $2 \mathrm{G}$ and $6 \mathrm{NG}$ amplified by PCR using the universal fungal primers (ITS1/ITS4) generated amplicons of $\approx 550 \mathrm{bp}$, which corresponded with the expected size for Fusarium species according to Abd-Elsalam et al. (2003). The PCR products from both samples were used for sequencing directly, and analysis of the obtained sequences by the BLAST- $n$ tool showed $99 \%$ identity with several Fusarium species (accessions KR815448.1 and KP721566.1, among others), which confirm Fusarium presence in grafted and nongrafted plants.

The production of thick-walled chlamydospore and colony-forming microconidia on short monophialides allowed the morphological identification of the fungus as F. oxysporum. The pathogenicity test performed with sample $2 \mathrm{G}$ on 'Sugar Baby' watermelon plants resulted in small cracks in stems, and presence of gumming was observed after $18 \mathrm{~d}$. Additionally, the plants showed a rapid decline of their stems, which were completely dried in conjunction with its leaves and tendrils. These symptoms on 'Sugar Baby' watermelon allowed the identification of the fungus causing the wilt of plants as FON (Kleczewski and Egel, 2011).

Fusarium symptoms depend on environmental factors, age of the infected plant, and the amount and aggressiveness of the pathogen (Kleczewski and Egel, 2011). Generally, adult plants show wilting and yellow foliage. Necrosis of the vascular tissue occurs, which can be seen as black spots when the roots are cut transversely (Latorre, 2004). Wilting is due to a reduction in plant water transport. The vascular bundles are plugged because of the formation of gummy and tylosis compounds (Martyn, 1996). The symptoms observed in the field during Expts. 1 and 2, along with the inoculated plants of 'Sugar Baby' watermelon (Expt. 2), are consistent with those described for fusarium wilt disease. 
Results from this study show a significant improvement in yield and quality of grafted watermelons when produced in a field naturally infested with fusarium wilt. However, economic justification of grafting depends on costs and benefits associated with the use of this technology. In Chile, additional cost of using grafted watermelon is $\approx \$ 0.60$ per plant. During the last 3 years, average price during full season (January and February) has been $\$ 1.60$ per fruit in premium watermelons, while $\$ 1.20$ is the price for second-grade fruit (Oficina de Estudios y Políticas Agrarias, 2015). In the case of 'Santa Amelia', the most common cultivar used in Chile, our results showed that grafted plants produced 1.6 fruit per plant compared with 0.9 fruit per plant with nongrafted plants. If fruit are sold at premium price, the income per grafted plant would be $\$ 2.56$, which is $\$ 1.12$ higher that the income from a nongrafted plant. If the fruit from the nongrafted plant were sold at the second-grade price, which is a more realistic scenario because of smaller size, the difference would be $\$ 1.48$. In both cases, the use of grafted watermelons ( $\$ 0.60$ additional cost per plant) would be economically justified. It is important to emphasize that the results of the cost benefit analyses of using grafted watermelon depend on variables such as level of disease pressure, it effects on yield, and fruit price (Taylor et al., 2008). Conditions that favor the decision of using grafted plants are cultivation in conditions that favor fusarium wilt incidence (i.e., infested soil, susceptible cultivar, furrow irrigation) and the expectation of high prices for the fruit (i.e., forced crops for harvesting early in the season).

In conclusion, when grown under an FON-infested field of the Chilean central region, grafting increased yield and quality of seeded and seedless watermelon cultivars. Production of more and larger fruit per plant would lead to higher income that would largely offset the costs of grafting, thus the technique appears highly recommendable for Chilean growers.

\section{Literature cited}

Abd-Elsalam, K.A., I.N. Aly, M.A. AbdelSatar, M.S. Khalil, and J.A. Verreet. 2003. PCR identification of Fusarium genus based on nuclear ribosomal-DNA sequence data. Afr. J. Biotechnol. 2:82-85.
Alan, Ö., N. Özdemir, and Y. Günen. 2007. Effect of grafting on watermelon plant growth, yield and quality. J. Agron. 6:362-365.

Alexopoulos, A., A. Kondylis, and $\mathrm{H}$. Passam. 2007. Fruit yield and quality of watermelon in relation to grafting. J. Food Agr. Environ. 5:178-179.

Bekhradi, F., A. Kashi, and M. Delshad. 2011. Effect of three cucurbit rootstocks on vegetative and yield of 'Charleston Grey' watermelon. Intl. J. Plant Prod. 5:105-109.

Bruton, B., W. Fish, W. Roberts, and T. Popham. 2009. The influence of rootstock selection on fruit quality attributes of watermelon. Open Food Sci. J. 3:15-34.

Davis, A. and P. Perkins-Veazie. 2005. Rootstock effects on plant vigor and watermelon fruit quality. Cucurbit Genet. Coop. Rpt. 28-29:39-42.

Davis, A., P. Perkins-Veazie, R. Hassell, A. Levi, S.R. King, and X. Zhang. 2008a. Grafting effects on vegetable quality. HortScience 43:1670-1672.

Davis, A., P. Perkins-Veazie, Y. Sakata, S. López-Galarza, J. Maroto, S. Lee, Y. Huh, S. Sun, A. Miguel, S.R. King, R. Cohen, and J. Lee. 2008b. Cucurbit grafting. Crit. Rev. Plant Sci. 27:50-74.

González-Torres, R., J. Meléro-Vara, J. Gómez-Vázquez, and R. Jiménez Díaz. 1993. The effects of soil solarization and soil fumigation on fusarium wilt of watermelon grown in plastic houses in southeastern Spain. Plant Pathol. 42:858-864.

Gusmini, G., J.R. Schultheis, and T.C. Wehner. 2004. Rind thickness of watermelon cultivars for use in pickle production. HortTechnology 14:540-545.

Hassell, R. and F. Memmott. 2008. Grafting methods for watermelon production. HortScience 43:1677-1679.

Huh, Y., W. Lee, H. Ko, D. Park, K. Park, H. Lee, S. Lee, and K. Ko. 2012. Development of fusarium wilt-resistant Fl hybrids of bottle gourd (Lagenaria siceraria Standl.) for watermelon rootstocks. Cucurbitaceae 2012. Proc. Xth EUCARPIA Mtg. Genet. Breeding Cucurbitaceae, Antalya, Turkey, 15-18 Oct. 2012, p. 74-82.

Kleczewski, N.M. and D.S. Egel. 2011. A diagnostic guide for fusarium wilt of watermelon. Online Plant Health Prog. doi:10.1094/PHP-2011-1129-01-DG.

Konica Minolta Sensing. 2007. Precise color communication: Color control from perception to instrumentation. $15 \mathrm{Dec}$. 2016. <http://www.konicaminolta.com/ instruments/knowledge/color/pdf/ color_communication.pdf $>$.
Kyriacou, M. and G. Soteriou. 2015. Quality and postharvest performance of watermelon fruit in response to grafting on interspecific cucurbit rootstocks. J. Food Qual. 38:21-29.

Latorre, B. 2004. Enfermedades de las plantas cultivadas. 6th ed. Ediciones Pontificia Universidad Católica de Chile, Santiago, Chile.

Lee, J. 1994. Cultivation of grafted vegetables I. Current status, grafting methods, and benefits. HortScience 29:235-239.

Lee, J., C. Kubota, S. Tsao, Z. Bie, P. Hoyos Echevarria, L. Morra, and M. Oda. 2010. Current status of vegetable grafting: Diffusion, grafting techniques, automation. Sci. Hort. 127:93-105.

Lodhi, M.A., G.N. Ye, N.F. Weeden, and B.I. Reisch. 1994. A simple and efficient method for DNA extraction from grapevine cultivars and Vitis species. Plant Mol. Biol. Rpt. 12:6-13.

Louws, F., C. Rivard, and C. Kubota. 2010. Grafting fruiting vegetables to manage soilborne pathogens, foliar pathogens, arthropods and weeds. Sci. Hort. 127:127146.

Martyn, R. 2012. Fusarium wilt of watermelon: A historical review. Cucurbitaceae 2012. Proc. Xth EUCARPIA Mtg. Genet. Breeding Cucurbitaceae, Antalya, Turkey, 15-18 Oct. 2012, p. 136-156.

Martyn, R.D. 1996. Fusarium wilts, p. 11-16. In: T.A. Zitter, D.L. Hopkins, and C.E. Thomas (eds.). Compendium of cucurbit diseases. APS Press, St. Paul, MN.

Miguel, A., J. Maroto, A. San Bautista, C. Baixauli, V. Cebolla, B. Pascual, S. López, and J. Guardiola. 2004. The grafting of triploid watermelon is an advantageous alternative to soil fumigation by methyl bromide for control of fusarium wilt. Sci. Hort. 103:9-17.

Mohamed, F., K. El-Hamed, M. Elwan, and M. Hussien. 2012. Impact of grafting on watermelon growth, fruit yield and quality. Veg. Crops Res. Bul. 76:99-118.

Oficina de Estudios y Políticas Agrarias. 2015. Precios: Series históricas de frutas y hortalizas. 15 Dec. 2015. <http://www. odepa.cl/precios/series-historicas-de-frutasy-hortalizas $/>$.

Oluk, C., V. Aras, E. Agcam, A. Akyldz, N. Sari, and M. Göcmen. 2012. Investigation on fruit quality of grafted watermelon. Cucurbitaceae 2012. Proc. Xth EUCARPIA Mtg. Genet. Breeding Cucurbitaceae, Antalya, Turkey, 15-18 Oct. 2012, p. 361-367.

Petropoulos, S., E. Khah, and H. Passam. 2012. Evaluation of rootstocks for watermelon grafting with reference to plant 
development, yield and fruit quality. Intl. J. Plant Prod. 6:481-492.

Pofu, K., P. Mashela, and D. De Waele. 2012. Survival, flowering and productivity of watermelon (Citrullus lanatus) cultivars in intergeneric grafting on nematoderesistant Cucumis seedling rootstocks in Meloidogyne-infested fields. Intl. J. Agr. Biol. 14:217-222.

Pulgar, G., G. Villora, D. Moreno, and L. Romero. 2000. Improving the mineral nutrition in grafted watermelon plants: Nitrogen metabolism. Biol. Plant. 43:607609.

Rivero, R., J. Ruiz, and L. Romero. 2003. Role of grafting in horticultural plants under stress conditions. Food Agr. Environ. 1:70-74.

Rouphael, Y., D. Schwarz, A. Krumbein, and G. Colla. 2010. Impact of grafting on product quality of fruit vegetables. Sci. Hort. 127:172-179.

Salam, M., A. Masum, S. Chowdhury, M. Dhar, M. Saddeque, and M. Islam. 2002. Growth and yield of watermelon as influenced by grafting. Online J. Biol. Sci. 2:298-299.
Taylor, M., B. Bruton, W. Fish, and W. Roberts. 2008. Cost benefit analyses of using grafted watermelon trasnplants for fusarium wilt disease control. Acta Hort. 782:343-350.

White, T.J., T. Bruns, S. Lee, and J. Taylor. 1990. Amplification and direct sequencing of fungal ribosomal RNA genes for phylogenetics, p. 315-322. In: M.A. Innis, D.H. Gelfand, J.J. Sninsky, and T.J. White (eds.). PCR protocols: A guide to methods and applications. Academic Press, San Diego, CA.

Yetisir, H., M. Çaliskan, S. Soylu, and M. Sakar. 2006. Some physiological and growth responses of watermelon [Citrullus lanatus (Thunb.) Matsum. and Nakai] grafted onto Lagenaria siceraria to flooding. Environ. Expt. Bot. 58:1-8.

Yetisir, H., S. Kurt, N. Sari, and F. Tok. 2007. Rootstock potential of Turkish Lagenaria siceraria germplasm for watermelon: Plant growth, graft compatibility, and resistance to Fusarium. Turk. J. Agr. For. 31:381-388.
Yetisir, H. and N. Sari. 2003. Effect of different rootstock on plant growth, yield and quality of watermelon. Austral. J. Expt. Agr. 43:1269-1274.

Yetisir, H., N. Sari, and S. Yücel. 2003. Rootstock resistance to fusarium wilt and effect on watermelon fruit yield and quality. Phytoparasitica 31:163-169.

Yetisir, H. and V. Uygur. 2009. Plant growth and mineral element content of different gourd species and watermelon under salinity stress. Turk. J. Agr. For. 33:65-77.

Zhang, M., X. Yang, G. Liu, J. Xu, L. Zhu, C. Gao, P. Li, and X. Yao. 2012. Histological differences between watermelon grafted onto bottle gourd rootstock and self-rooted seedlings inoculated with Fusarium oxysporum f. sp. niveum. Cucurbitaceae 2012. Proc. Xth EUCARPIA Mtg. Genet. Breeding Cucurbitaceae, Antalya, Turkey, 15-18 Oct. 2012, p. 299-305. 